\title{
PLUŽNA PRI BOVCU, \\ PRIMER TRANSFORMACIJE OBMEJNEGA NASELJA, NJEGOVEGA PREBIVALSTVA IN ZEMLJIŠČA
}

\author{
Jurij Kunaver*
}

Izvleček

UDK $911 \cdot 373$ (497.12 Plužna)

Predstavljene so naravne razmere, razvoj gospodarstva in prebivalstva ter sedanje socialnoekonomske razmere majhne vasi Plužna kot izrazito depopulacijskega obmejnega naselja.

Ključne besede: lokalna geografija, depopulacija, Bovško

\section{PLUŽNA BY BOVEC: A CASE OF TRANSFORMATION OF A SETTLEMENT BY THE BORDER, ITS POPULATION AND LANDS}

Abstract

UDC $911 \cdot 373$ (497.12 Plužna)

Presented are natural conditions, economy-and population developments, and the current socio-economic conditions of a small village, Plužna, a characteristic settlement by the state border with pronounced depopulation.

Key words: Local geography, Depopulation, State border vicinity, the Bovec area

\section{UVOD}

Za podrobnejšo analizo naselja Plužna ${ }^{1}(461 \mathrm{~m})$ pri Bovcu smo se odločili zaradi izredno velikega nazadovanja njegovega prebivalstva, največjega na ožjem Bovškem. Hkrati pa ugotavljamo, da ima zaradi prisojne podgorske lege pod Kaninskim pogorjem in precej ravnega sveta razmeroma ugodne pogoje za skromnejše kmetijstvo in za razvoj turizma. Plužna so sicer odmaknjena od glavne prometnice, vendar je po stranski asfaltirani cesti komaj tri kilometre do Bovca, po makadamski cesti pa je mogoča še krajša neposredna zveza do glavne ceste pri Podklopci.

Zastavili smo si nalogo, da skušamo odkriti globlje vzroke za tako močno nazadovanje naselja, saj je v njem prebivalo ob prvem štetju leta 1869251 ljudi, danes pa šteje samo še 49 stalnih prebivalcev. V naselju so vse številnejši začasni prebivalci vikendaši, ki v svoje roke postopoma prevzemajo izpraznjene hiše ali celo gradijo nove. Več kot stoletno izgubljanje prebivalstva se je začelo že v drugi polovici prej-

\footnotetext{
*Dr., prof., Oddelek za geografijo, Filozofska fakulteta Univerze v Ljubljani, Aškerčeva 2, 61000 Ljubljana, Slovenija

' Domača oblika imena je množinska: Plužna, sem iz Plužen, grem na Plužna, je na Plužnah, Pluženčani.
} 
šnjega stoletja (Sedmak, 1994). Plužna pa so v tem stoletju doživele še druge usodne udarce, ki so pregloboko zarezali v njene prebivalstvene korenine, da bi se mogla demografsko obnoviti ali vsaj stagnirati.

Prvi je Plužna omenjal Melik (1962), pozneje pa so jih zgodovinsko, naselbinsko, demografsko in etnološko podrobneje obravnavali avtorji v zborniku Pokrajina in ljudje na Bovškem (Stres, Dolenc, (1) in (2)), Kovač, Benedejčič in Miklavčič-Brezigar, vsi 1988). Relief je opisal Kunaver (1975). Najnovejša omemba Plužen je v Sedmakovi razpravi (1994). Pri našem delu smo si pomagali z dosedanjimi ugotovitvami, s franciscejskim katastrom, $s$ kartiranjem rabe tal in zlasti s pričevanjem domačinov. ${ }^{2}$

\section{KRATKA ZGODOVINA PLUŽEN}

Melik citira Kosa in piše, da se Plužna imenujejo že v urbarju iz 1. 1257, kar pomeni, da spadajo med najstarejša bovška naselja ("In contrata de Pletio, In villa de Plusina", KOS, 15, 278, Melik, 1962, 335). Po Marušiču se prvič omenjajo leta 1285, kar je le enajst let za Bovcem in istočasno kot Srpenica (Marušič, 1971, str. 13). V tem se odraža takratni pomen lege Plužen na osončenem in dovolj prostranem zemljišču pod Kaninskim pogorjem, nedaleč od takratne ceste, ki se ji je približala v dolini Glijuna.

V 1. svetovni vojni je vas delila podobno usodo kot mnoga druga naselja na ožjem Bovškem. 24. maja 1915 zvečer so $v$ cerkvi pri šmarnicah prebivalce obvestili, da morajo še isto noč zapustiti vas. Vaščani Plužen so vzeli s seboj le krave, medtem ko so drobnica in prašiči postali plen italijanske vojske. Vas je bila $v$ času soške fronte $v$ celoti porušena. Italijanska vojska je nato na širšem območju vasi postavila barake, pozneje pa še manjšo bolnico in vojaško pokopališče.

\section{LEGA VAŠKEGA ZEMLJIŠČA IN NARAVNI POGOJI}

Na vsem podnožju Kaninskega pogorja, od slapa Boke do Kluž, so prav na območju Plužen in sosednjega razloženega naselja Zavrzelna še najboljše razmere za obdelovanje in za naselitev. Plužna so nastala na zgornjem robu širokega in položnega pluženskega polja, točno na prehodu $v$ nekoliko strmejši morenski svet. Ves ta svet pripada kaninskemu podnožju, ki se $\mathrm{v}$ obliki klina zajeda visoko navzgor $\mathrm{v}$ kaninska pobočja do okrog $850 \mathrm{~m}$ (Gošča, Vegenca).

Med Plužnami in Zavrzelnim je kaninsko podnožje najširše in ima značaj razmeroma položnega pobočja s povprečnim nagibom od 14 do 18 stopinj. Zgrajeno je $v$ glavnem

\footnotetext{
${ }^{2}$ Za pomoč pri zbiranju podatkov in nasvete se iskreno zahvaljujem ge Bibijani Flajs, g. Andreju Miheliču-Bedenu, in g. Ivanu Šulinu-Johanu iz Plužen, ter ge Darinki Kravanja in g. Andreju Stergulcu iz Bovca.
} 
iz krednega fliša, $v$ nekoliko višjih legah pa tudi iz starejših krednih kamnin (Jurkovšek, 1987). Zato so strmejše stopnje bolj redke, razen na območju morenskih nasipov. Flišna podlaga prihaja na dan le na redkih krajih, ker je kamninska podlaga $v$ Bovški kotlini, pa tudi od doline Ročice do začetka strmejših apnenčastih pobočij, večinoma različno debelo prekrita $\mathrm{z}$ ledeniškimi in holocenskimi sedimenti. Flišne primesi so običajne $v$ morenskem gradivu $v$ nižjih legah, medtem ko jih $v$ morenah kaninskih stadialnih ledenikov, ki so ob koncu würma segli do istega podnožja, v glavnem ni (Kunaver, 1975).

Slika 1: Pogled na Plužna od jugovzhoda. Zadaj ostenje Peči s predkvartarno erozijsko teraso Na pečah $(900-1000 \mathrm{~m})$, območjem pluženskih prestaj ali predplanin. Povsem v ozadju višja pobočja Kaninskega pogorja s skednji (foto Kunaver).

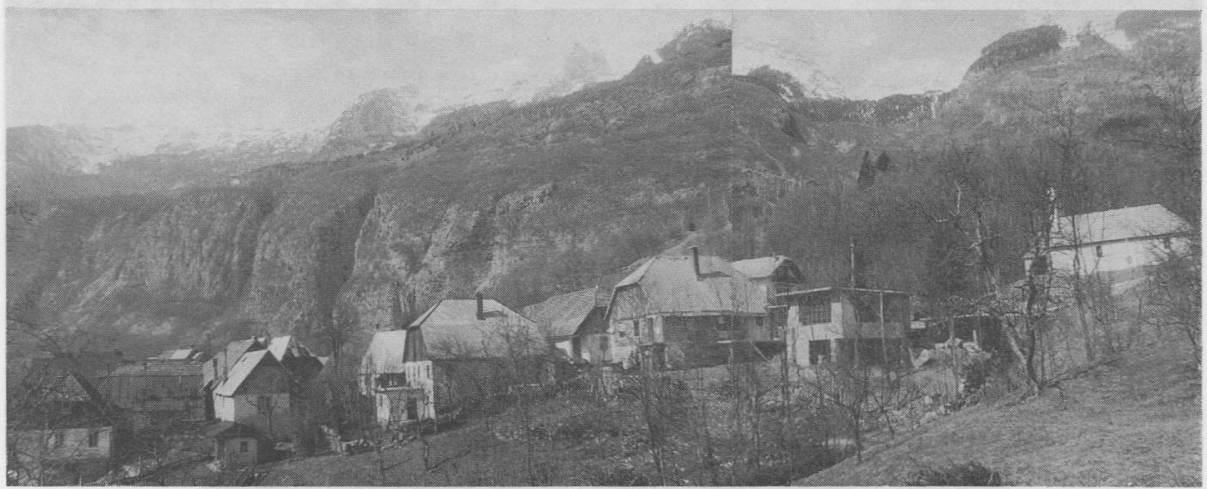

V zahodnem delú širšega pluženskega ozemlja, med izvirom Glijuna, ostenjem Peči na severni in kamnitimi pobočji Poljance na južni strani, je kaninsko podnožje najožje, oziroma se spremeni $v$ dolinski zatrep, zapolnjen $z$ ledeniškimi sedimenti. Ostenje Peči, kjer se še danes pasejo koze iz Plužen, se začne na okrog $500 \mathrm{~m}$.

Kaninsko podnožje med Bovcem in Plužnami nad desnim bregom Ročice lahko razčlenimo $v$ naslednje pokrajinskoekološke enote (graf 1 ), ki si sledijo vzporedno ena nad drugo:

1. najnižji je pas strmih, erozijsko močno razrezanih pobočij z grapami $v$ flišni podlagi na desnem bregu Ročice, ki jih porašča mlad mešan gozd bukve, jesena, gabra, jelše in drugih listavcev. Intenzivnejše rabe površja razen paše tudi v preteklosti ni bilo.

2. Pas pomolov med erozijskimi grapami, ki imajo nagnjeno plosko površje, prekrito z ledeniškimi sedimenti. $\mathrm{V}$ tem delu je največ uravnanega sveta med Bovcem in Plužnami. Nekdanja raba je bila delno njivska, delno travniška. Danes kosijo le posamezne dele zemljišča, večinoma pa so travniki že močno zaraščeni. 
Slika 2: Dolinski zatrep na območju izvira Glijuna med Pečmi (na desni) in Poljanco (na levi) se vedno močneje zarašča (foto J. Kunaver).

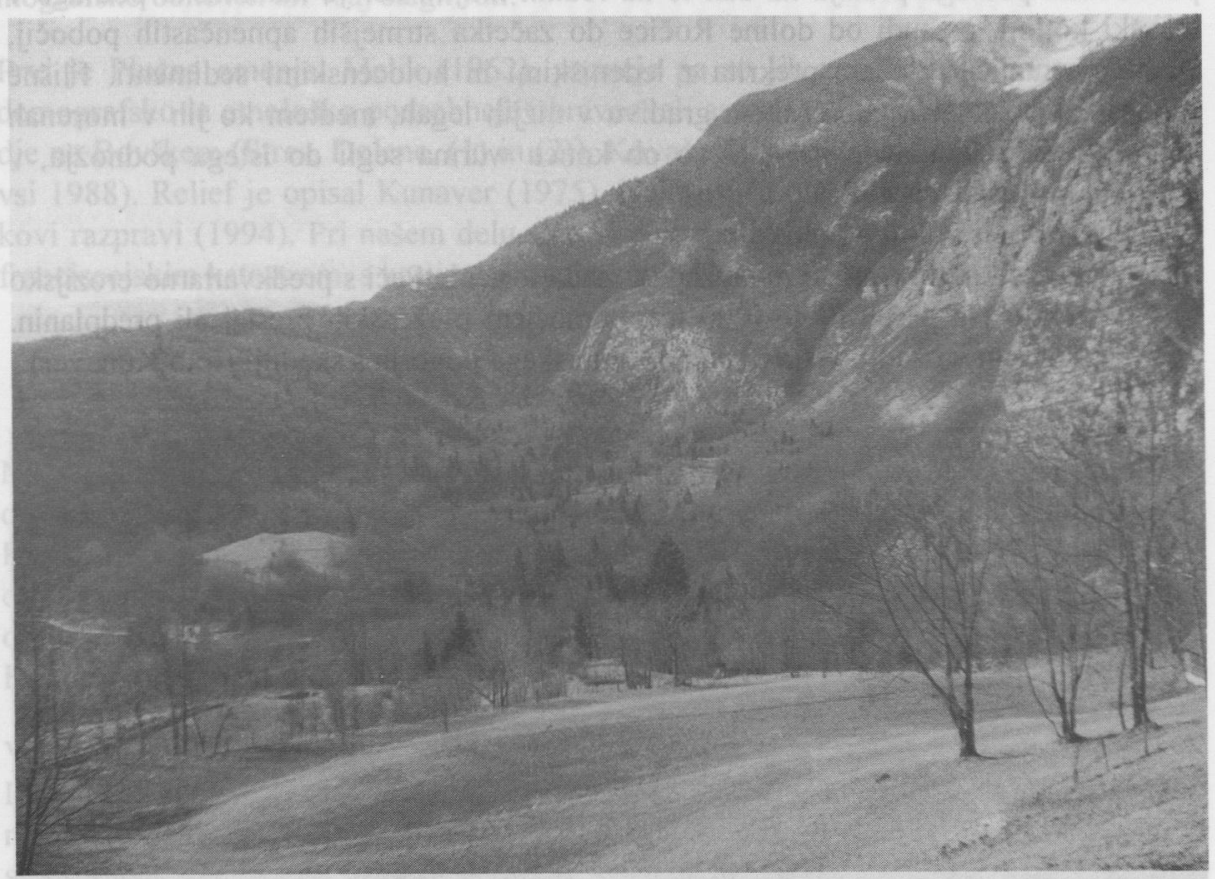

Ta pas pomolov v višini okrog $400-500 \mathrm{~m}$, kamor sodi tudi od grap nerazrezano terasasto plužensko polje, je območje nekdanje proglacialne sedimentacije in drugih procesov tik pod čelom stadialnih kaninskih ledenikov. Od tod prekritost flišne podlage $\mathrm{z}$ različno debelo odejo pretransportiranega ledeniškega gradiva s prevlado karbonantih prodnikov, kar je pomembno za nevtralizacijo sicer kisle flišne podlage. Plužensko polje je najširši pomol, saj merì v širino od doline Glijuna do prve naslednje grape skoraj 500 metrov. Na posameznih širših pomolih je dovolj prostora tudi za manjšo kmetijo (kmetija Pri Mocelnu).

Plužna so postavljena na severovzhodni ogel pluženskega polja na pregib med položnejšim svetom pod njim in strmejšim nad njim. Naselje je torej nastalo na tistem delu polja, ki je bilo najbližje Bovcu in kjer ni bilo večje škode zaradi izgubljenega plodnega zemljišča.

3. Naslednji je pas razgibanega morenskega reliefa, ki se kot celota in v posameznih odsekih strmo dvigne skoraj kot stopnja nad prejšnjo reliefno enoto. Ker stadialni ledeniki niso segali povsod enako globoko in čelne morene niso enako izrazite, je zato 
meja med 2. in 3. enoto na Zavrzelnem in v smeri proti Bovcu nekoliko vijugasta. To mejo zelo jasno kaže potek ceste Bovec-Plužna, ker je večina morenskih nasipov tik nad njo, tudi $v$ cestnem vzponu na odseku Zavrzelno-Plužna, kjer so najnižje ležeče morene krniškega stadialnega ledenika.

$\mathrm{V}$ tem pasu oziroma enoti, ki ima slabše reliefne in talne pogoje za kmetijstvo od prejšnje, je nastalo razloženo naselje Zavrzelno, ki se proti vzhodu nadaljuje v Visna in Pod robom nad Bovcem. V podobnih pogojih sta na širšem območju Plužen nastali samotni kmetiji Pri Jouzlnu in Trnjer (glej sl. 3). Med različno ohranjenimi čelnimi in bočnimi morenskimi nasipi, ki so največkrat med seboj vzporedni in običajno potekajo $\mathrm{v}$ smeri strmca, so enako usmerjene vmesne globeli, ki so bile pomembne za intenzivnejšo obdelavo. Na mnogih krajih so jih pregradili s podpornimi zidovi, škarpami ali "kaštami" in s tem ustvarili manjše ravne njivice (Hrvatin, 1988, str. 77-79). Za izrabo so bile pomembne tudi posamezne terase, katerih pojav med morenskimi nasipi je nekoliko nenavaden in jim zato pripisujemo kemijski nastanek (Kunaver, 1975, str. 31-32).

Slika 3: Domačija Pri Trnjerju je postavljena na medmorenski terasi tik pod žlebom, ki so ga izdelali vode in ledeniški tokovi, tekoči iz doline Krnice. Hiša bovškega tipa je modernizirana s prizidkom (foto J. Kunaver).

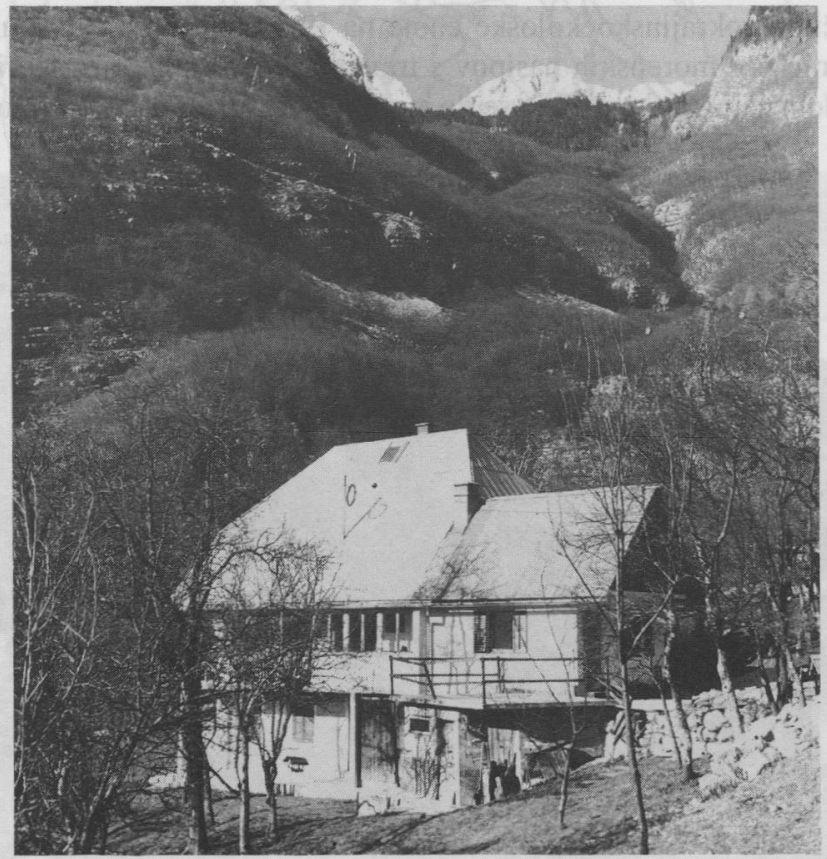


4. Razgiban svet morenskih nasipov se nadaljuje navzgor v naslednjo, najvišjo pokrajinskoekološko enoto položnejšega kaninskega podnožja, katere značilnost je razmeroma tanka plast morenskega gradiva, vmes pa so po površju raztreseni precej številni ledeniški balvani. Bolj ali manj enakomerno se dvigujoče pobočje je bilo v spodnjem delu nekoč skupna vaška last Plužen in sosednjega Zavrzelnega, danes pa se v celoti zarašča. Značilni so brinovi grmi, grmovja robidnice in neredko tudi večje površine zaraščene s praprotjo. V višjih legah se je zaraščanje začelo še bolj zgodaj in je zato do danes močno napredovalo $v$ različno star gozd. Značilno je, da je razmeroma strmo pobočje neposredno nad središčem vasi, ki sega do nekdanje obmejne karavle, tudi že močno zaraščeno, deloma celo z okrog 40 let starim gozdom, kar je posledica strmine in slabe, celo mokrotne podlage iz trdo zbite talne morene, odložene na flišno podlago.

5. Zadnja enota na ožjem območju Plužen so strmejša apnenčasta pobočja Peči in melišča pod njimi, ki so v preteklosti lahko služila izključno za kozjo pašo in tako je $\mathrm{v}$ manjši meri še danes. Zaradi zmanjšane paše so se ta pobočja $v$ zadnjih desetletjih močneje obrasla z malim jesenom in črnim gabrom. Gospodarski prostor Plužen je segal še na hrbet Poljance, kjer so bili travniki in pašniki ter prestaje in na Velike in Male lazne nad izvirom Glijuna. V podobne namene kot Poljanca je služilo tudi nekoliko položnejše površje na vrhu Peči, kjer so bile prestaje na Planini na Pečeh, na Hciru, $\mathrm{Na}$ brdu in $\mathrm{Na}$ čelu. Plužna so po tradiciji lahko izkoriščala planino Krnico, ki je bila najboljše pašno območje v Kaninskem pogorju.

Slika 4: Značilne pokrajinskoekološke enote na Plužnah: pod vasjo plužensko polje, nad njo pas morenskih nasipov s travniki, ki se zaraščajo, še višje z mladim gozdom zaraščeni pašniki vse do strmih apnenčastih pobočij (foto J. Kunaver).

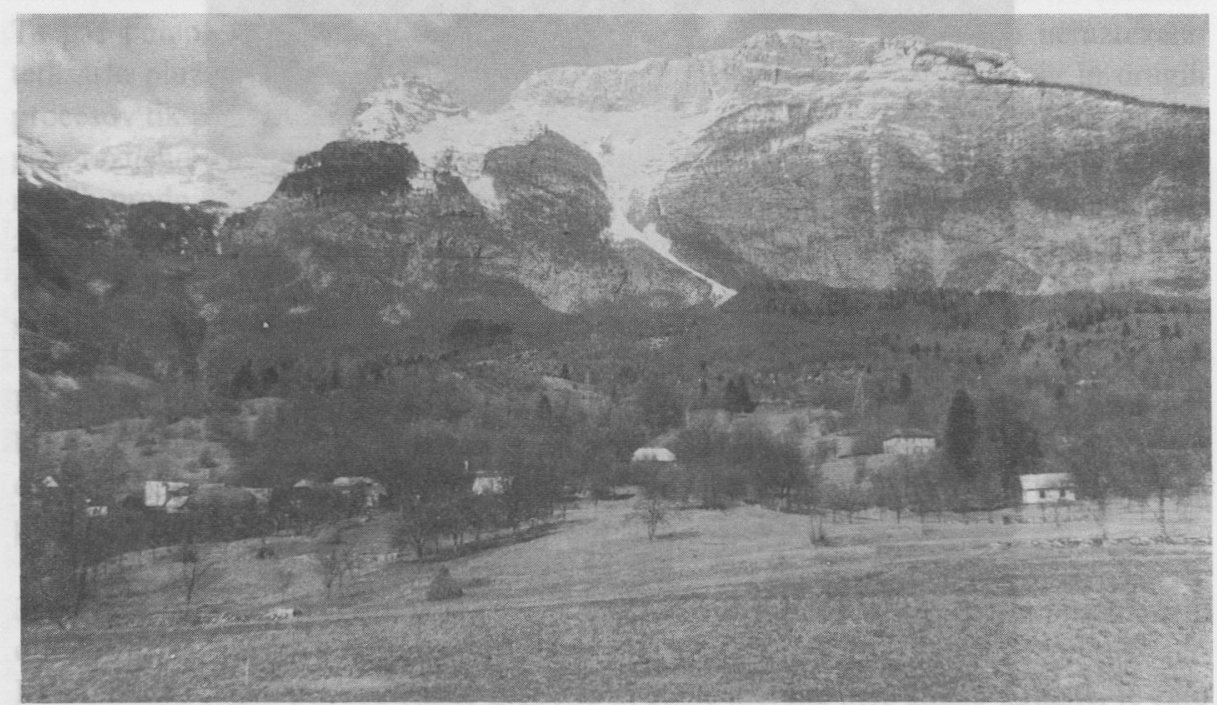




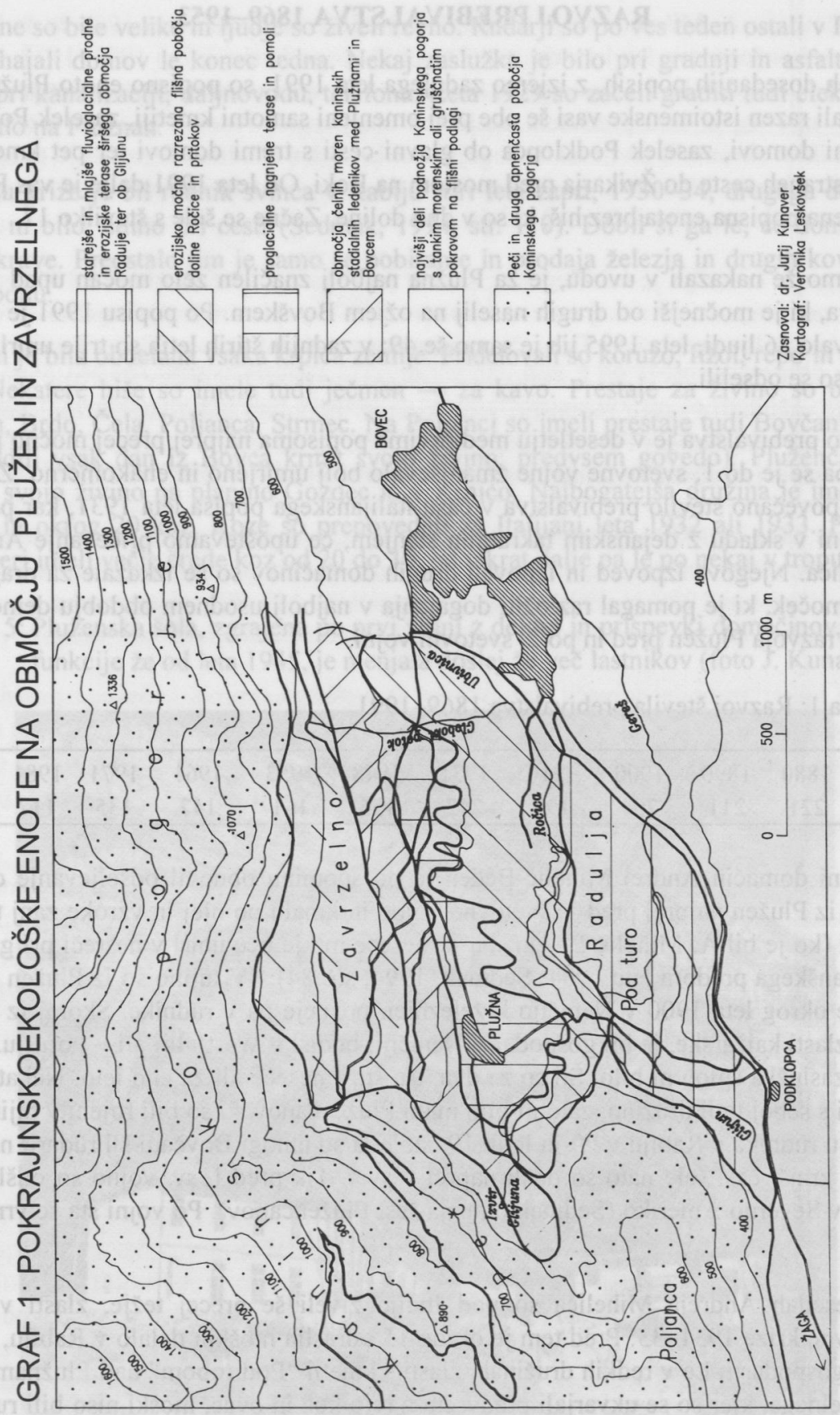




\section{RAZVOJ PREBIVALSTVA 1869-1953}

V vseh dosedanjih popisih, z izjemo zadnjega leta 1991, so popisno enoto Plužna sestavljali razen istoimenske vasi še obe prej omenjeni samotni kmetiji, zaselek Pod turo s tremi domovi, zaselek Podklopca ob glavni cesti s tremi domovi ter pet kmetij na obeh straneh ceste do Žvikarja pred mostom na Boki. Od leta 1991 dalje je vas Plužna okrnjena popisna enota brez hiš, ki so v dnu doline. Začne se šele s številko 17.

Kot smo že nakazali v uvodu, je za Plužna najbolj značilen zelo močan upad prebivalstva, ki je močnejši od drugih naselij na ožjem Bovškem. Po popisu 1991 je v vasi prebivalo 56 ljudi, leta 1995 jih je samo še 49: $v$ zadnjih štirih letih so trije umrli, štirje pa so se odselili.

Število prebivalstva je $v$ desetletju med prvima popisoma najprej precej močno padlo, nato pa se je do 1 . svetovne vojne zmanjševalo bolj umirjeno in enakomerno. Značilno je povečano število prebivalstva $v$ času italijanskega popisa leta 1931, kar pa verjetno ni $v$ skladu $z$ dejanskim takratnim stanjem, če upoštevamo pričevanje Andreja Miheliča. Njegova izpoved in izpoved drugih domačinov so se izkazale za dragocen pripomoček, ki je pomagal razložiti dogajanja $v$ najbolj usodnem obdobju demografskega razvoja Plužen pred in po 2. svetovni vojni.

Tabela 1: Razvoj števila prebivalstva 1869-1991

\begin{tabular}{cccccccccccc}
\hline 1869 & 1880 & 1890 & 1900 & 1910 & 1931 & 1948 & 1953 & 1961 & 1971 & 1981 & 1991 \\
251 & 221 & 211 & 204 & 198 & 242 & 155 & 161 & 147 & 135 & 117 & 56 \\
\hline
\end{tabular}

92-letni domačin Andrej Mihelič-Beden je po spominu obnovil odseljevanje domačinov iz Plužen najprej pred 1 . svetovno vojno in kmalu po njej in vzroke zanj takole opisal (ko je bil A. Mihelič-Beden star 4 mesece mu je oče umrl v nesreči pri gradnji karavanškega predora leta 1904; Sedmak, 1994, str. 84): "V tujino so iz Plužen odhajali že okrog leta 1900 v Nemčijo k železnici, pozneje pa v rudnike. Skoraj iz vsake hiše, zlasti kajžarske, je bil gospodar v Nemčiji, bodisi v Westfaliji ali v Porurju. Drugega zaslužka sploh ni bilo. Šli so za dva, tri, štiri mesece ali za eno leto. Nekateri so peljali s seboj tudi družino, zato ni bilo malo Pluženčanov, ki so bili rojeni v tujini. Po odprtju rudnika v Rablju v 90 -ih letih 19. stoletja so mnogi Bovčani šli rudarit najprej tja za krajši čas, šele nato so odšli naprej v svet. Tik pred l. sv. vojno so odšli prvi štirje v Severno Ameriko (Sedmak omenja šest Pluženčanov). Po vojni sta se vrnila le dva".

Po besedah Andreja Miheliča so pod Italijo živeli še precej težje, zlasti v času svetovne krize 1931-33. Pred tem je okrog 15 odraslih moških delalo v Rablju, zlasti hišni gospodarji. Le v redkih družinah, zlasti s kmetij "Pod robom" nad Plužnami in z Zavrzelnega, kjer so se ukvarjali predvsem z rejo koz in ovac, moški niso bili rudarji. 
Družine so bile velike in ljudje so živeli revno. Rudarji so po ves teden ostali v Rablju in prihajali domov le konec tedna. Nekaj zaslužka je bilo pri gradnji in asfaltiranju cest, pri kanalizaciji, daljnovodu, telefonu. Leta 1929 so začeli graditi tudi električno centralo na Plužnah.

V času krize je bil rudnik svinca v Rablju štiri leta zaprt, 1930-34, drugega dela pa doma ni bilo, edino pri cesti (Sedmak, 1994, str. 110). Dobil si ga le, če doma nisi imel krave. Preostalo jim je samo še pobiranje in prodaja železja in drugih kovin po Rombonu.

V vasi je bila obdelana vsaka krpica zemlje. Pridelovali so koruzo, fižol, repo in krompir. Nekatere hiše so imele tudi ječmen - za kavo. Prestaje za živino so bile na Pečah, Brdo, Čela, Poljanca, Strmec. Na Poljanci so imeli prestaje tudi Bovčani (trije so hodili vsak dan iz Bovca krmit svojo živino, predvsem govedo). Pluženčani so gnali svojo živino na planino Gozdec in v Krnico. Najbogatejša družina je imela 50 ovac in okrog 20 koz. Koze so prepovedali že Italijani leta 1932 ali 1933. Prej so nekateri imeli večje črede koz od 20 do 30 , od takrat dalje pa le po nekaj v tropu ovac.

Slika 5: Pluženska šola, zgrajena po prvi vojni z delom in prispevki domačinov, izven funkcije že od leta 1945, je menjala doslej že več lastnikov (foto J. Kunaver).

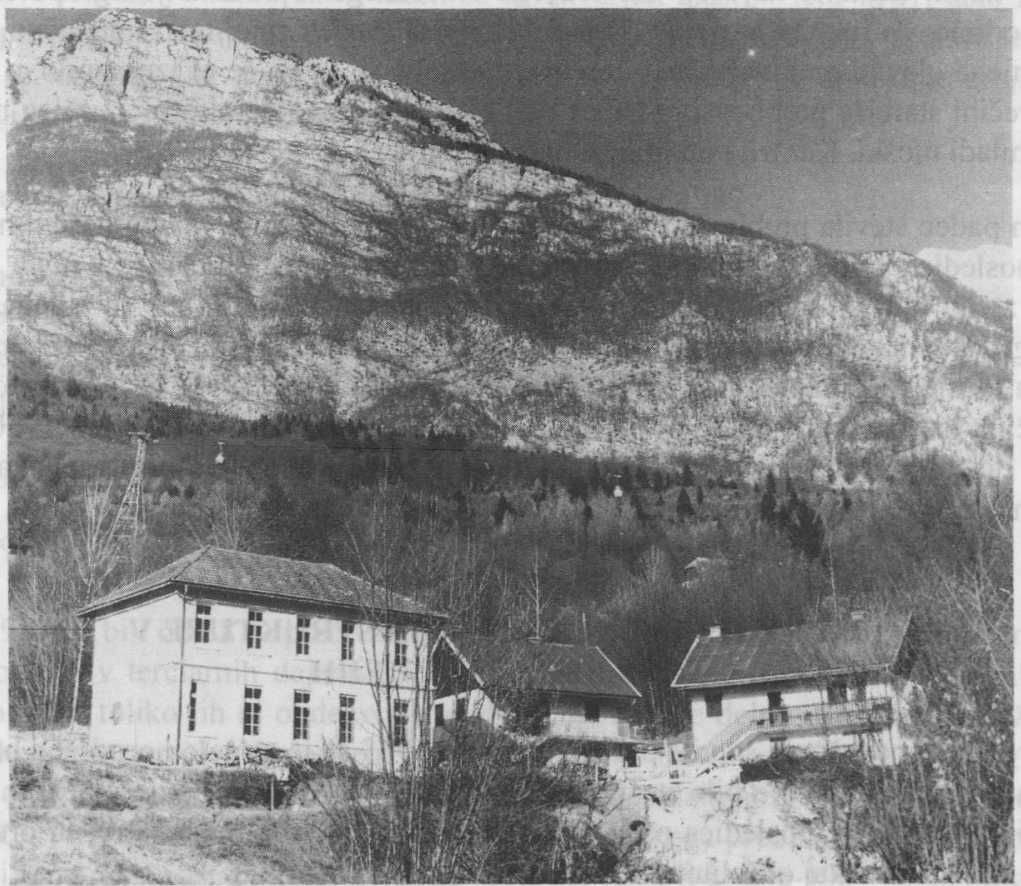


Po pričevanju A. Miheliča se je močnejše odseljevanje začelo leta 1926 in je bilo v glavnem končano dve leti kasneje, torej še pred gospodarsko krizo 1931-1933. Mladi moški so odhajali zlasti v Francijo in Belgijo, ne pa $v$ Argentino, kljub propagandi. To izseljevanje naj bi bilo predvsem posledica brezperspektivnosti, ki jo je $v$ takratnih omejenih in skromnih življenskih pogojih čutila vaška mladina. Omeniti je treba tudi neko družino iz Plužen, ki se je izselila v Jugoslavijo takoj po koncu 1. svetovne vojne, zaradi nasprotovanja novi oblasti.

Izseljevanje iz Italije je bilo legalno, še več pa ilegalno. V času popisa 1931 so bili mnogi posamezniki že nekaj časa v tujini, a so jih v popisu najbolj verjetno še vedno vodili kot stalne prebivalce. Drugače si ni mogoče razlagati tako velikega števila prebivalstva kljub temu, da je po 1 . svetovni vojni, po povratku beguncev na svoje domove, mogoče računati $z$ večjo rodnostjo prebivalstva. Podobno sliko kažejo tudi nekateri drugi kraji v Zgornjem Posočju, čeprav je vzrok za povečano število prebivalstva v večjih krajih prisotnost vojaštva in italijanskih uradnikov (Sedmak, 1994, str. 109).

Med leti 1926 in 1928 je Plužne zapustilo okrog 35 mlajših moških. Za nekaterimi so odšla tudi vaška dekleta. Zgornjo številko smo dobili iz poimenskega seznama izseljencev med leti 1926 in 1928, ki ga je sestavil A. Mihelič za vse osebe po posameznih hišah. Le šest domačinov se je še pred 2. svetovno vojno vrnilo domov.

Vas je takrat izgubila največji del svojega človeškega reprodukcijskega potenciala. Zato sodimo, da je prav ta pojav, ki je mlade ljudi Plužen zajel tako množično, spodrezal njene glavne prebivalstvene korenine. Naselje se s tem še ni izpraznilo, a ostalo je povečini starejše prebivalstvo ter ne ravno številni mladoletni otroci, poleg njih pa redki mladi moški. Kar trije od njih se niso poročili.

Močan padec števila prebivalstva po zadnji vojni (štetje leta 1948) po našem mnenju ni le posledica vojnih izgub, ki so prizadele sicer tudi to vas ampak se v njem najbrž delno zrcali tudi opisano množično izseljevanje konec dvajsetih let. To sklepamo na podlagi Miheličevih podatkov za predvojni in povojni čas. Po 2. svetovni vojni so v Rablju ostale tri družine in en posameznik. Čez mejo je zbežalo pet domačinov, pet domačink pa je odšlo v razne kraje, $v$ Trst, Nemčijo in v Avstrijo. Po letu 1950 se je izven Plužen poročilo pet domačink. S tem je zaključeno obdobje izseljevanja iz Plužen. Tu je treba omeniti, da se je na Plužna $v$ istem času priženilo šest žensk.

\section{PREBIVALSTVENI RAZVOJ IN STRUKTURE V ZADNJIH DESETLETJIH}

Po skromnem povečanju števila prebivalcev leta 1953 se je pričelo nezadržno padanje števila prebivalstva, ki je bilo najmočnejše $v$ zadnjih dveh desetletjih, zlasti med leti 1981 in 1991. To je posledica padca rojstev, najbolj pa odmiranja starejših prebivalcev. Bilo je tudi nekaj odselitev v Bovec in drugam po državi. 
Tabela 2: Starostna sestava prebivalcev leta 1987 leto rojstva štev. preb. leto rojstva štev. preb.

\begin{tabular}{rrrr}
$1890-99$ & 0 & $1940-49$ & 13 \\
$1900-09$ & 4 & $1950-59$ & 2 \\
$1910-19$ & 2 & $1960-69$ & 5 \\
$1920-29$ & 12 & $1970-79$ & 8 \\
$1930-39$ & 5 & $1980-87$ & 2 \\
\hline & skupaj & 53 \\
\hline
\end{tabular}

Analiza in razlaga demografskega razvoja Plužen, tudi s pomočjo pričevanja najstarejšega še živečega prebivalca Plužen, je bila potrebna zato, da je mogoče razumeti tudi druge posledice takega razvoja na naselje, njegovo zemljišče in na vse Zgornje Posočje, katerega sestavni del je obravnavana pokrajina. O posledicah takega in podobnega demografskega razvoja na Plužnah, na Bovškem in v Zgornjem Posočju je v literaturi že precej objavljenega, predvsem o zaposlitvenem prestrukturiranju, opuščanju obdelovalnih površin, ozelenjevanju in ogozdovanju oziroma vsesplošnem zaraščanju in spreminjanju pokrajine itd. (Kovač, 1988; Hrvatin, 1988; Benedejčič, 1988; Kunaver, 1991; Kunaver, 1994).

S prebivalstvenimi strukturami Plužen so se ukvarjali zlasti v letu 1987, zato z njim lahko primerjamo stanje ob popisu leta 1991 in sedanje razmere. A v sedmih letih do danes se niso zgodile posebno velike spremembe, kar kaže na umirjanje prejšnjega procesa naglega upadanja števila prebivalstva.

Tabela 3: Poklicna sestava prebivalcev na Plužnah leta 1987

\begin{tabular}{lcc} 
Aktivno prebivalstvo & $22 /$ & $41,5 \%$ \\
Upokojenci & $14 /$ & $26,42 \%$ \\
Vzdrževane osebe & $17 /$ & $32,08 \%$ \\
\hline Skupaj & 53 & $100,00 \%$ \\
\hline
\end{tabular}

Vir: Kovač, 1988

Leta 1991 je bilo vzdrževanih oseb 32 .

Leta 1987 so bili od $38 \%$ prebivalcev, zaposlenih v industriji, trije rudarji, eden pa je bil zaposlen $v$ terciarnih dejavnostih. Le $31 \%$ anketiranih je takrat obdelovalo vso zemljo, prav toliko jih ni obdelovalo zemlje, $38 \%$ pa le delno, oziroma le bližnje in lažje dostopne parcele. V glavnem so opustili košnjo travnikov (70\%), kot poglavitni vzrok $(75 \%)$ pa so navedli ostarelost, ostali pa oddaljenost in pomanjkanje časa (Kovač, 1988, str. 58). Leta 1991 je bilo število kmečkega prebivalstva nekoliko višje, a pravi kmet je $v$ vasi že dolgo le eden. Vsi trije rudarji iz leta 1987 so se po zaprtju 
rudnika leta 1991 upokojili. Leta 1987 je bilo ugotovljeno, da je v vasi malih kmetij 12 ali $63,2 \%$ in srednjih 7 ali $37,8 \%$. Ta podoba ni najbolj realna, vendar pa odraža vsaj to, da ima skoraj vsaka stalno naseljena hiša oziroma vsaka družina, tudi samski posamezniki, še precej obdelovalne zemlje.

Tabela 4: Število aktivnih preivalcev po gospodarskih vejah leta 1987 in 1991

\begin{tabular}{lrr} 
& 1987 & 1991 \\
\hline kmetijstvo & 2 & 4 \\
industrija, rudarstvo & 15 & 12 \\
trgovina, turizem & 2 & 3 \\
šlstvo, zdravstvo, kultura & 1 & 1 \\
komunala, promet & 1 & 1 \\
ostalo & 1 & 1 \\
\hline Skupaj & 22 & 22 \\
\hline
\end{tabular}

\section{VAŠKO ZEMLJIŠČE IN IZRABA TAL}

Melik poudarja pomen in vrednost pluženskega obdelovalnega zemljišča, ki je razdeljeno v nepravilne grudaste delce. Daleč največ obdelovalne zemlje je bilo na pluženskem polju, kot imenujemo obširno, $v$ nevisokih stopnjah in položnih odsekih se znižujoče zemljišče, ki se na spodnjih straneh zaključi s strmimi ježami nad dolinami Glijuna, Ročice in Gomilico. Primerjava med franciscejskim katastrom in današnjim stanjem kaže naslednjo podobo. Leta 1825 je bilo njivskega sveta na pluženskem polju okrog ena tretjina vseh površin, $v$ njegovem spodnjem delu pa več kot polovica. Ostalo so bili travniki in v zelo majhnem deležu travniki s sadovnjakom.

Današnje stanje na pluženskem polju kaže, da se je večina nekdanjih njiv spremenila v travnike. Domačini so ohranili predvsem vrtove na zahodni strani polja, ki so $\mathrm{v}$ isti višini kot naselje, za pridelavo krompirja in stročnic. Zelo redke so posamezne še obdelane njive v drugih, zlasti nižjih delih polja. Čeprav je plužensko polje primerno za strojno obdelovanje, se tudi tu že pojavljajo nekateri nepokošeni travniki.

Vse ostale vaške površine, zlasti nekdanji travniki na pobočjih nad Glijunom in Ročico, so opuščeni že vsaj 25 let in jih prerašča sekundaren gozd. Še dalj časa traja zaraščanje nekdanjih pašnikov ali vaške gmajne, zlasti pa od prepovedi paše koz po letu 1950. Pokrajinski videz robnih vaških zemljišč na območju dolinskega zatrepa nad izvirom Glijuna, hriba Poljance in pobočij Peči, se je zaradi mladega gozda temeljito spremenil (Kunaver, 1994, str. 236-237).

S kmetijstvom se na Plužnah preživlja le ena družina. Nekateri domačini še kosijo travnike na pluženskem polju, ne samo svoje ampak tudi sosedove. Vendar pridelanega sena zaradi vse manjšega števila živine zase ne potrebujejo več. Občasno ga 
prodajajo bodisi kmetijski farmi $v$ Bovcu ali drugim kupcem, vendar stalnega povpraševanja ni. Na Plužnah je bilo leta 1995 vsega 5 glav goveje živine, od tega le ena molznica. Koz je bilo 35 in okrog 60 ovac, vendar se število drobnice med letom lahko močno spreminja.

\section{RAZVOJ IN STANJE NASELJA}

Plužna kot naselje opisuje Melik takole: "Plužna presenečajo po svojem tločrtu, ki razodeva razpoloženost domov skoro $\mathrm{v}$ štirikotniku, okrog središčnega prostora, ki je v njem vodnjak. Samo severna stran tega štirikotnika je bolj slabo izražena, o ostalih treh pa ne moremo dvomiti. Najmočnejša je južna stranica, a zadaj za njo se tesno tiščijo še novo prirastle hiše, naslonjene na slabotno cestico, ki drži $v$ dolino na veliko cesto" (Melik, 1962, str. 331).

Opisani tločrt Plužne je brez dvoma zanimiv za proučevalca razvoja podeželske naselitve, ker je pomembna gradbeno-arhitektonska dediščina. Zato se sedanji tločrt in videz naselja ne bi smela bistveno spreminjati, obnoviti pa bi bilo treba vse stavbe, ki so v slabem stanju. Plužna predstavljajo tudi v pokrajinsko-estetskem smislu naselbinsko in krajinsko vrednoto, kar dokazujejo pogledi nanjo z različnih strani. Zaradi teh lastnosti in neperspektivnosti kmetijstva se že dalj časa vsiljuje misel, da bi lahko več pomenila na področju turistične ponudbe. A to bi se smelo zgoditi le ob čim večji udeležbi domačinov, ne pa brez njih. Toda dosedanji razvoj zaenkrat ne kaže na to. Miklavčič-Brezigarjeva (1988, str. 95-99) je leta 1987 skupaj z mladimi raziskovalci obdelala Plužno z vidika naseljenosti in strukture družin. Njene ugotovitve lahko primerjamo $\mathrm{z}$ današnjim stanjem in $\mathrm{S}$ popisom leta 1991 (graf 2). Zlasti se kaže postopno večanje števila počitniških hiš in števila opuščenih hiš. Od leta 1992 dalje ter v zadnjem času se močno povečuje število novih interesentov za nakup opuščenih hiš ali za gradnjo novih hiš za počitniške namene na Plužnah. To je jasen dokaz izrazite transformacije naselja iz nekdanjega kmečko-rudarskega prek kmečkodelavskega v mešano obliko kmečko-delavsko-počitniškega tipa naselja.

Tabela 5: Naseljenost vasi Plužna

\begin{tabular}{lrrr} 
& 1987 & 1991 & 1995 \\
\hline stalno naseljene hiše & 19 & 23 & 19 \\
opuščene hiše (prazne) & 3 & 6 & 9 \\
$\begin{array}{l}\text { začasno nenaseljene } \\
\text { počitniške hiše }\end{array}$ & 2 & & \\
$\begin{array}{l}\text { hiše v obnovi } \\
\text { ruševina s številko }\end{array}$ & 21 & 24 & 22 \\
ruševina brez številke & 4 & & 1 \\
\hline Skupno stanovanjskih hiš & 47 & 55 & 52 \\
\hline
\end{tabular}




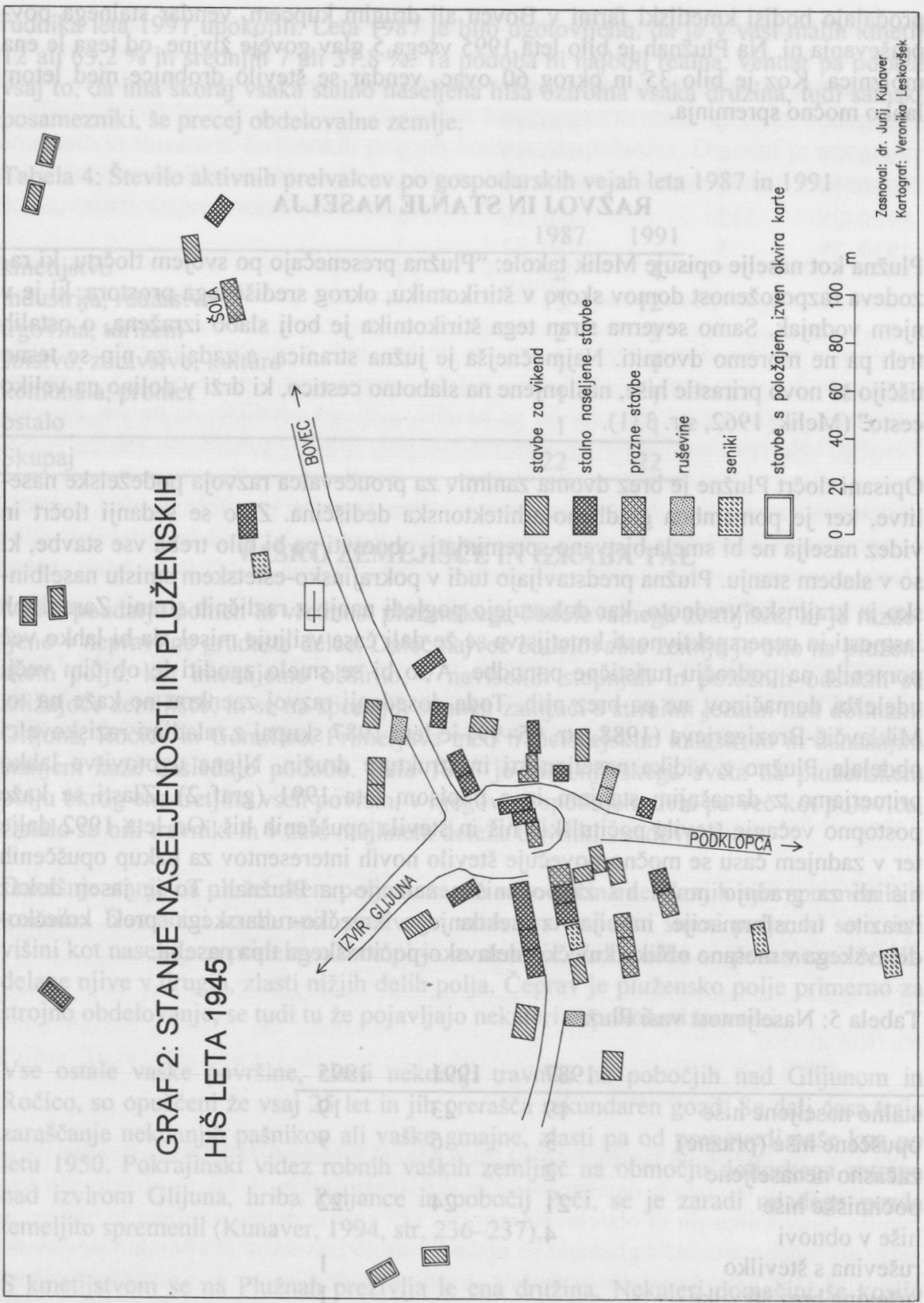


Na ožjem območju Plužen je tudi precej manjših gospodarskih poslopij, tako starejših registriranih in nekaj tudi neregistriranih. Vas nima niti trgovine niti gostilne (bila je do 1. svetovne vojne), čeprav je bilo narejenih že več poskusov, da bi vaščanom olajšali oskrbovanje $\mathrm{z}$ najosnovnejšimi potrebščinami.

Tabela 6: Število članov gospodinjstev leta 1987

$\begin{array}{lccccccc}\text { vsa } & \text { kmečka } & \text { nekmečka } & 1 \text { član } & 2 \text { člana } & 3 \text { člani } & 4 \text { člani } & 5 \text { članov } \\ 23 & 7 & 16 & 8 & 8 & 1 & 3 & 1\end{array}$

Miklavčič-Brezigarjeva je obravnavala tudi probleme, povezane s strukturo družin in ugotavlja, da v 12 stalno naseljenih hišah živi nepopolna družina ( $\mathrm{v} 6$ po eden, $\vee 6$ po dva ostarela zakonca), otroci so $v$ Bovcu, na Žagi ali drugod. V tej odseljeni generaciji je le ena družina $z$ več kot 4 otroci, ostale družine imajo le po enega ali dva otroka. Leta 1987 je bila na Plužnah le ena družina s starši, mlajšimi od 35 let in le dve, kjer živijo skupaj s starimi starši. Generacija od 35 do 65 se je torej v celoti izselila. Leta 1995 sta bila v vasi samo dva otroka, stara do 14 let.

\section{ZAKLJUČEK IN PERSPEKTIVE}

Pojav razkroja socialne strukture nekdanjega kmečko-rudarskega in pozneje kmečko-rudarsko-delavskega naselja Plužna pri Bovcu sam na sebi ni posebnost, zlasti glede na njegov periferni, obmejni in podgorski položaj. Kaže pa neke samosvoje poteze, zaradi katerih je bilo treba osvetliti ozadje njegovega razvoja. Plužna so imela relativno velike kmetijske površine ter pašnike in planine na Kaninskem pogorju, a za preživetje relativno številnega prebivalstva to ni zadoščalo. Zato je bil nujno potreben dodatni dohodek, bodisi od rabeljskega rudarstva, dela $v$ industriji, ali pa zaposlitev $v$ zamejstvu. Do 2. svet. vojne je za številne mlade Pluženčane ostala zapolsitev v tujini edina možna alternativa. S tem je plužensko prebivalstveno jedro že pred 2. vojno izgubilo svoje najpomembnejše korenine. Najbolj drastično se je zmanjšalo prebivalstvo po letu 1926, kar je statistika zabeležila šele po 2. vojni. Takrat pa so že tudi presahnila rojstva, ko so se preostali mladi ljudje izselili v Bovec ali drugam in ko so pričeli umirati starejši Pluženčani. To se najbolj kaže v popisih med letoma 1971 in 1991.

Plužna preseneča $v$ primerjavi $z$ drugimi naselji na ožjem Bovškem po svojem položaju, ki naravnost kliče $\mathrm{k}$ razvoju za turistično oziroma počitniško dejavnost. A razen vedno večjega števila počitniških hiš, ki so nastale iz nekdanjih kmečkih domov ali pa so $v$ manjši meri prezidane oziroma temeljito obnovljene, pravega turizma $v$ tem kraju ni. Plužna kljub bližini Bovca, niso bila privlačna niti kot spalno naselje za delavce oziroma uslužbence, zaposlene $\vee$ Bovcu, razen za redke, ki izvirajo iz vasi. Kljub praznim hišam je bil samo en primer začasne naselitve $v$ vasi. Plužna torej postopoma 
izgubljajo svojo nekdanjo funkcijo in se spreminjajo $\mathrm{v}$ mešano kmečko-delavsko-počitniško naselje. Vprašanje je, kakšen delež domačega prebivalstva, ki se intenzivneje ukvarja z zemljo in negovanjem krajine, bi bilo treba ohraniti, da bi pokrajina še naprej obdržala vsaj del svojega nekdanjega videza. Zaenkrat si ni mogoče predstavljati, da bi bilo nazadovanje domačega prebivalstva še naprej tako močno kot doslej, in da bi $v$ naselju prevladali tuji prebivalstveni elementi, ki s tradicijo naselja niso dovolj povezani. Kljub temu se glede nosilcev nadaljnega razvoja lahko upravičeno vprašamo, kdo bo tisti, ki bo znal vsaj nekoliko obuditi življenje na Plužnah, in znal ceniti ter izkoristiti osnovne naravne danosti? Preostali domačini ali priseljenci, ali oboji skupaj?

\section{LITERATURA IN VIRI}

Benedejčič, M. 1988: Bovško kot obmejna regija. Pokrajina in ljudje na Bovškem. Zbornik Alpski mladinski raziskovalni tabori, Bovec, 1985-1987. Gibanje Znanost mladini, ZOTKS. Ljubljana.

Jurkovšek, B. 1987: Tolmač listov Beljak in Ponteba. Osnovna geološka karta $1: 100.000$. Beograd.

Dolenc, J. 1988: Prispevek za zgodovino Bovškega pod Italijo 1918-1941 (Delo zgodovinske sekcije 2. AMRT v Bovcu, 29.6.-7.7. 1986). Pokrajina in ljudje na Bovškem. Zbornik Alpski mladinski raziskovalni tabori, Bovec, 1985-1987. Gibanje Znanost mladini, ZOTKS. Ljubljana.

Dolenc, J. 1988: Prispevek za zgodovino Bovškega 1942-1947. Pokrajina in ljudje na Bovškem. Zbornik Alpski mladinski raziskovalni tabori, Bovec, 1985-1987. Gibanje Znanost mladini, ZOTKS. Ljubljana.

Gosar, A. 1978: Rast in razporeditev delovnih mest nekmečkih dejavnosti kot faktor oblikovanja območja koncentracije prebivalstva in gospodarstva. Zgornje Posočje. 10. zborovanje slovenskih geografov, Tolmin-Bovec, 1975, str. 159-166. Ljubljana.

Hrvatin, M. 1988: Nekatere značilnosti zemljiške razdelitve in novejše spremembe izrabe tal na Bovškem. Pokrajina in tjudje na Bovškem. Zbornik Alpski mladinski raziskovalni tabori, Bovec, 1985-1987. Gibanje Znanost mladini, ZOTKS. Ljubljana.

Klemenčič, M. 1982: Depopulation of Slovene Alps. Referat na simpoziju Sub-Commission on Rural Development in Highlands and High-Latitude Zones, Lapland.

Klemenčič, M. 1984: Some geographical characteristics of agriculture in the slovene alpine area. Geographica Iugoslavica V, 1983, str. 65-70. Ljubljana.

Klemenčič, V. 1984: Population growth in the slovene alpine area. Geographica Iugoslavica V, 1983, str. 91-98. Ljubljana.

Kovač, S. 1988: Značilnosti gibanja in struktur prebivalstva Bovškega v novejšem času. Pokrajina in ljudje na Bovškem. Zbornik Alpski mladinski razișkovalni tabori, Bovec, 1985-1987. Gibanje Znanost mladini, ZOTKS. Ljubljana. 
Kunaver, J. 1975: H geomorfološkemu razvoju Bovške kotline v pleistocenu. Geografski vestnik 47, str. 11-41. Ljubljana.

Kunaver, J. 1991: Nekatere oblike transformacije geografske podobe Zgornjega Posočja. Geografska problematika severovzhodne Slovenije. Dela 8, str. 138-142. Oddelek za geografijo Filozofske fakultete Univerze v Ljubljani.

Kunaver, J. 1994: Povojna usoda Bovškega v luči obmejnosti in perifernosti. Soški protokol. Izdajatelja Andreas Moritsch/Gudmund Tributsch, uredil Harald Krahwinkler. Mohorjeva založba, Celovec-Ljubljana-Dunaj, str. 227-242.

Melik, A. 1954: Slovenski alpski svet. Slovenija, geografski opis II, 1. zv. Ljubljana.

Melik, A. 1962: Bovec in Bovško. Regionalna geografska študija. Geografski zbornik, VII. str. 307-388, SAZU. Ljubljana.

Miklavčič-Brezigar, I. 1988: Prispevek k etnološki podobi Bovškega. Zbornik Alpski mladinski raziskovalni tabori, Bovec, 1985-1987. Gibanje Znanost mladini, ZOTKS. Ljubljana.

Stres, P. 1988: Prebivalstvo Bovškega v času soške fronte. Pokrajina in ljudje na Bovškem. Zbornik Alpski mladinski raziskovalni tabori, Bovec, 1985-1987. Gibanje Znanost mladini, ZOTKS. Ljubljana.

Sedmak, D. 1994: Ekonomska in politična migracija prebivalstva na Bovškem v letih 1850 do 1940. Soški protokol. Izdajatelja Andreas Moritsch/Gudmund Tributsch, uredil Harald Krahwinkler. Mohorjeva založba, Celovec-Ljubljana-Dunaj, 1994, str. 79-125.

\section{PLUŽNA BY BOVEC: A CASE OF TRANSFORMATION OF A SETTLEMENT BY THE BORDER, ITS POPULATION AND LANDS}

\section{Summary}

Plužna is a small village lying at the foot of the Kanin mountains, near the Italian state border. Natural conditions are mean for farming, due to very agitated landforms and the karstic nature of the surface. The number of residents in the village reduced in the past 100 years from 250 to 50 . The main causes for such development were, as follows: The villagers always had to earn a living, besides farming on the nearby land, by working outside their village. Towards the end of the $19^{\text {th }}$ century, young men used to go for a few months' seasonal work in Germany; at the turn of the century, they used to work in the nearby lead mine at Cave del Predil, and just before the outbreak of World War II, many of them left for the USA. In the time between the two wars, when this area was under the Italian rule, men were employed in the lead mine at Cave del Predil or found job in the construction or repairing works on roads, cable lines, power plants, etc. Some villagers left for France and Belgium to find work there. After World War II, emigration continued. 